\title{
A ideia de poiésis na Teologia Cristã
}

\begin{abstract}
Arquivo recebido em
1 de outubro de 2012

e aprovado em
\end{abstract}

19 de novembro de 2012

V. 2 - N. $4-2012$
Alex Villas Boas*

\section{Resumo}

$\mathrm{O}$ que acontece metodologicamente entre a Teologia Neotestamentária e Veterotestamentária volta a se repetir com a passagem para o mundo grego, em que há uma continuidade e uma descontinuidade. A

${ }^{*}$ Concluindo o doutorado em Teologia pela Pontifícia Universidade Católica do Rio de Janeiro (PUC-Rio), onde atua como professor convidado. Mestre em Teologia pela Pontifícia Faculdade de Teologia Nossa Senhora da Assunção (PUC-SP), Bacharel em Teologia pelo Instituto de Teologia João Paulo II (2005). Membro Pesquisador do Grupo de Estudos em Literatura, Religião e Teologia (LERTE-PUC-SP), do Centro de Estudos Medievais Oriente e Ocidente do Departamento de Filosofia e Ciências da Educação da Universidade de São Paulo (CEMOrOc-USP). Membro e Coordenador do GT de Religião, Arte e Literatura da Sociedade Brasileira de Teologia e Ciências da Religião

(SOTER). Professor de Teologia na Escola Dominicana de Teologia (EDT), Instituto de Teologia São Paulo (ITESP) e no Instituto de Teologia João Paulo II em Sorocaba-SP. Professor de Filosofia e Coordenador da Pós-graduação latu sensu em Religião e Cultura no Centro Universitário Assunção

UNIFAI. Membro desde a fundação da Associação Latino Americana de Literatura e Teologia

(ALALITE) e editor da Revista Brasileira de Literaturas e Teologias Teoliterária. Principais trabalhos publicados: Teologia e Poesia - A busca de sentido em meio às paixões em Carlos Drummond de Andrade como possibilidade de um pensamento poético teológico. Sorocaba-SP: Crearte Editora, 2011; A Mística Poética como Reinvenção da Própria Vida ou a Poesia de Si em Santa Teresa D’Avila. In: PÁDUA, Lucia Pedrosa; CAMPOS, Monica Pereira. (Org.). Santa Teresa: Mística para o nosso tempo. Rio de Janeiro: Editora Reflexão, 2011, p. 161-188; Entre a Teografia e a Teologia. Teografia I - Sentimento Religioso e Cosmovisão Literária. Aveiro: Editora da Universidade de Aveiro, 2011,p. 267-287; A proposta de uma Teopatodiceia como pensamento poético-teológico. Ciberteologia, São Paulo, v. 36, p. 23-54, 2011; A paixão pela Palavra que une literatos e teólogos. In: ROCHA, Alessandro; YUNES, Eliana; CARVALHO, Gilda.. (Org.). Teologias e Literaturas. São Paulo-SP: Fonte

Editorial, 2011, p. 101-128; Dos teus lábios aos meus. In: Jean Luiz Lauand. (Org.). Filosofia e

Educação: Estudos 8. São Paulo: CEMOrOc/EDF-FEUSP/Factash Editora, 2008, p. 73-85; Padre

Antonio Vieira: 4o. Centenário de um Teólogo desconhecido (Homenagem ao Pe. Antonio Vieira apresentado na Academia Paulista de Letras). Revista de Cultura Teológica, v. 16, p. 147-182, 2008. 
exigência do diálogo com a filosofia grega acaba por transpor a poiésis em logos, não sendo contudo uma sobreposição, mas antes uma justaposição em que ora caminham em paralelo, ora se integram. Há uma teologia patrística filosófica e uma teologia patrística poética. A ideia de poiesis aqui trabalhada será extraída do pensamento de Clemente de Alexandria e Gregório de Nazianzo.

Palavras-chave: Teologia e Literatura, Poiésis e Logos, Clemente de Alexandria, Gregório de Nazianzo.

\section{Abstract}

What happens methodologically between Old Testament and New Testament theology back to repeat itself with the move to the Greek world, where there is a continuity and discontinuity. The requirement of dialogue with Greek philosophy eventually transpose poiesis in logos, although it was not an overlap, but rather a juxtaposition that sometimes go in parallel, sometimes integrate. There is a philosophical patristic theology and poetic patristic theology. The idea of poiesis worked here will be extracted from the thought of Clement of Alexandria and Gregory Nazianzen.

Keywords: Literature and Theology, poiesis and Logos, Clement of Alexandria, Gregory of Nazianzen.

"Poeta , id est, Dei imitator" Christianus Ravius (1613-1677)

urian e Smith elencam 42 gêneros que compõe a ideia de Literatura Cristã ${ }^{1}$ e boa parte destes estão presente inclusive na Patrística entendida como Literatura Cristã Antiga ${ }^{2}$. Pode-se, com isso, identificar uma poética formal presente nos hinos com temas de inspiração bíblica, presente embrionariamente datado a segunda meta-

1. "Apocalyptic Literature, Apocryphal Literature, Apologetics, Apostolic Fathers, Bible as Literature, Biography and Autobiography, Children's Literature, Christian Drama, Christmas and Christian Festivals, Christological Literature, Church History, Biblical Commentaries, Conversion Literature, Creation Literature, Creedal and Early Conciliar Literature, Devotional Literature, Bible Translations, Epistles and Collected Letters, Fiction, Gender Literature, Gospels, Hagiography, Hermeneutical Texts, Liturgies, Media and Periodical Literature, Medieval Literature, Meditational Prose, Missiologies, Missions Literature, Monastic Literature, Mystical Writings, Pastoral Instructions, The Penitentials as Literature, Poetry, Prayer, Reference Works, Sermons and Homilies, Social Ethics, Songs and Hymns, Spiritual Formation and Counsel, Systematics, Women's Literature" cf. KURIAN, George Thomas; SMITH, James D. The Enciclopedia of Christian Literature, 2010.

2. MORESCHINI, Claudio; NORELLI, Enrico. História da Literatura Cristã Antiga Grega e Latina, 1996 e 2000. 
de do século II desde a época pré-constantina em um primeiro momento como a Ode a Salomão com 42 poemas escritos em grego proveniente de uma comunidade judaico-cristã da Síria com uma temática próxima à teologia joanina, mas também apropriada ao mundo qumrânico. Também há registro de um Hino a Virgem Maria escrito em forma de salmo abecedário no estilo da poesia latina do século III. Ainda neste período, na segunda metade do século III se encontra as Instruciones e Carmen apologeticum de Comodiano, de datação incerta, marcado por um acento milenarista expondo a história da salvação como a luta entre dois povos, um puro e um impuro.

Somente com o início do período-constantino é que se inicia uma poesia parafrástica, representante da cultura oficial do Império Cristão, como reescritura da Bíblia ou das vidas de santos, considerada um prolongamento da lectio divina tida como alimento da alma do poeta ${ }^{3}$. É nesse momento que temos nomes como Juvencus (cc. 330dC) e Sedulio (425-450dC) como poetas cristãos, mas também há uma hinografia ligada a liturgia como a obra Ante saecula qui manes ou Fefelit saevam e ainda a Adae carnis de Hilário de Poitiers inseridas no contexto da controvérsia ariana, e principalmente de Ambrósio de Milão, como grande hinógrafo latino do Ocidente cristão, também anti-ariana ${ }^{4}$. Há também o surgimento da homilia métrica criada por Efrem, o sírio, o principal poeta da era patrística, seguido de Romano, o Melodo, considerado o "Pindaro cristão" por sua profunda inspiração e alto lirismo. No Ocidente, a poesia lírica cristã é representada por Prudêncio (348-405dC) inserindo-se na disputa contra os judeus, pagãos e marcionitas.

Nesse período constantino um dos gêneros muito utilizados pelos poetas cristãos são a centonaria que denota idéia de cento, uma peça de tecido que pode ser uma cortina ou capa composta por diversas pe-

3. DELL'OSSO, Carlo. Poesia e Teologia nei Padri In CATTANEO, Enrico; DE SIMONE, Giuseppe; DELL'OSSO, Carlos; LONGOBARDO, Luigi. Patres Ecclesiae, pp. 267-278.

4. Os principais hinos de Ambrósio são Aeterne rerum conditor; Deus creatur omnibum; Iam surgit hora tertia e Intende qui regis Israel. Cf. Ibidem, p. 269-271. 
ças de pano. O mais famoso autor é Proba Faltonia (cc. 360dC). Outro gênero famoso é o epigrama em versos hexamétricos cujos autores conhecidos são o papa Damaso (366-384). Destaca-se ainda, no século V, o nome do bispo Paulino de Nola com seus panegíricos e sua subentendida teologia atenta as necessidades materiais e espirituais dos pobres, destinatários primeiros da ação do bispo nolano. No século VI destaca-se o nome de Venanzio Fortunato com extensa produção literária com poesia de ocasiões, relíquias, epígrafos, epitáfios, panegíricos, e sobretudo, por sua hagiografia escrevendo suas Vitae em prosa ${ }^{5}$.

Entretanto, apesar dessa poética formal, há ainda um pensamento poético-teológico privilegiando a categoria poiésis no labor da mensagem e reflexão cristã. Na Teologia dos quatro sentidos, como chamou Henri de Lubac em sua Exégèse Médiévale ${ }^{6}$ a respeito da maneira de interpretar a literatura bíblica pela teologia patrística e medieval ${ }^{7}$ há uma certa razão literária no desenvolvimento do labor teológico em que o sentido anagógico, tido como espiritual está contido no elemento literário (sentido literal), transposto para uma outra forma de "poema-imagem" a fim de que permaneça sua marca de beleza [caligrama] para outro universo simbólico, permitindo assim que o modo de agir seja significativo, pois o belo manifesta a então "incompreensível bondade", que assumida conduz à dimensão anagógica. Lubac mostra como esta dimensão sofreu várias interpretações ao longo da história, desde o sentido espiritual, para o teológico, e ainda o escatológico, variando seu sentido como "razão" ou "espírito" das Escrituras ${ }^{10}$. Contudo, esse caminho do sentido visa atingir uma mira profunditas, uma "contemplação profunda" do Mistério, pois "as Escrituras estão plenas de um profundo

5. Ibidem, pp. 274-275.

6. "Littera gesta docet, quid credas alegoria/Moralis quid agas, quo tendas anagogia" cf. LUBAC, Henri de. Exégèse Médiévale - Les quatre sens de l'Écriture, p. 23.

7. Mesmo sendo o seu trabalho sobre exegese medieval, Lubac trabalha desde a escola teológica da Alexandria do segundo século.

8. Ibidem, Exégèse Médiévale, p. 162.

9. Ibidem, p. 120.

10. Ibidem, p. 122. 
sentido místico"11 e sendo assim de natureza mistérica "a Escritura é como o mundo: indecifrável em sua plenitude e na sua multiplicidade de sentidos"12, uma "floresta de significado infinito", "verdadeiro labirinto", "céu profundo", "abismo insondável", "mar imenso", "velas enfunadas", "oceano de mistério" porque as Escrituras em sua forma literária são "capax Spiritus Dei" ${ }^{13}$ e seu sentido mais profundo, a saber o místico, se manifesta com uma "teofania" pois as Escrituras explicam aquilo que a criatura experimenta ${ }^{14}$. Esta luz mais esclarecedora da divindade escondida é atingida pela contemplação das imagens ou signos literários que constituem a "superfície das Escrituras" como espelho das "formas sensíveis do mundo", e assim a Escritura é como que o "sacramento" e "símbolo" da criação, pois ambas carregam um caracter divino, um "aspecto visível e sensível" de modo que ambas, a Escritura e a criação são como que as vestimentas de Cristo, que podem ser lidas na experiência sensível da letra que contém o Espírito, ou seja, pela contemplação. Nesse sentido, a anagogia da exegese patrística e medieval é melhor entendida como experiência sensível de comunhão, ou seja, experiência afetiva que permite acolher o sentido efetivo dos fatos contidos no sentido literal das Escrituras, uma experiência de sentido unitivo com Deus. E aqui está a "fecundidade da Escritura"15 que de acordo com o autor, desde Bernardo, depois de Orígenes, Santo Agostinho, Santo Hilário, entre outros que defendem essa multiplex intelligentia que "engedra" um sentido de "diversas maneiras de compreender, acomodada às disposições e as necessidades diversas da alma" de modo que a Escritura é capaz de a todos reluzir, o que exige uma aproximação da letra com uma "douta ignorância" e não com um pretenso saber definitivo e de sentido

11. "l'Écriture est pleine d'un profond sens mystique". Cf. idem.

12. "L'Écriture est comme le monde: est comme le monde: «indéchiffrable dans sa plénitude et dans la multiplicité de ses sens". Cf. Ibidem, p. 119.

13. "infinita sensuum silva" cf. Ibidem, pp. 120-121.

14. "Scriptura explicat quae criatura probat". Cf. Ibidem, p. 125.

15. "fecondité de l'Écriture" cf. ibidem, p. 123. 
exclusivo, para lembrar Nicolau de Cusa ${ }^{16}$.

Tal poética não se caracteriza pela harmonia ou métrica, mas pela "força e solidez" de cunhar uma "visão de mundo" ${ }^{17}$, não de modo meramente informativo, mas de modo performativo em que o sentido é apreendido como algo "do próprio coração"18 que se apropria do "sentido de Cristo" por se manifestar apropriado a si mesmo configurando-se nele uma identidade. Este sentido em sua dimensão objetiva é o "sentido das Escrituras" ${ }^{19}$ porém na dimensão subjetiva ${ }^{20}$, como sentido apropriado às suas disposições e necessidades interiores, é um "sentido dado pelo Espírito" ${ }^{21}$ que tem como efeito uma intelligentia spiritualis.

Com efeito, a Escritura contém a "inteligência da vida espiritual"22 enquanto é "grávida" do Espírito de Cristo mas é este, por sua vez que permite a "realização" do significado do Evangelho na vida da pessoa, pois "vivifica" o sentido, como que tornando-o vivo na medida em que passa a assimilar a espiritualidade de Cristo como novo modo de vida na consciência de ser filho amado pelo Pai, e disposto a viver em uma comunhão de vontades com Ele na busca do Reino de Deus que opera como "princípio interior" da leitura de si e do entorno.

Para a Patrística o objeto essencial das Escrituras é o Cristo, mas que é assimilado subjetivamente como movimento interior na dimensão do pathos, afetando o modo de viver, a percepção da vida e do agir paulatinamente configurando não à imitação padronizada, mas que ins-

16. "Inexplicabilis divinae Scripturae fecunditas per diversos diverse explicatur, ut in varietate tanta ejus infinitas clarescat; unus tamen est divinum verbum in omnibus relucens" Cf. Idem.

17. Ibidem, p. 161.

18. "de corde próprio" cf. Ibidem, Seconde Partie - I, p. 100.

19. Ibidem, Premier Partie - I, p. 355.

20. Lubac apresenta como a dimensão subjetiva pode ser entendida como "sentido próprio". Porém a dimensão subjetiva foi lida em chave de "heresia" por alguns autores que atribuíram a inadequação do discurso a um sentido ortodoxo tido como referencial de objetividade, como Jerônimo, por exemplo, ocasionando em um pré-conceito desta dimensão antropológica, contida na experiência de fé na qual se desenvolve a inteligência espiritual. Cf. Ibidem, Secondie Partie - I,

"Subjetivisme et Inteligence Spirituelle", pp. 99-113.

21. Idem.

22. "spiritualis vitae inteligenttiam" cf. Ibidem, p. 356. 
pira uma reinvenção da própria vida, nessa comunicação idiomática, ou seja, do modo de ser (communicatio idiomatum). Esse sentido ainda que em um dinamismo subjetivo, não está dissociado da objetividade que contém o Cristo como elemento essencial do qual emerge o sentido, e portanto, há uma "dialética cristã" ${ }^{23}$ que contempla essa performance da inteligência espiritual entre o Tempo e o Agir. O sentido de Cristo marca a existência e com a percepção de um novo projeto existencial, no qual vislumbra algo de seu devir. Na novidade do Evangelho há um sentido de Homo novus venit que provoca a reflexão de si no Tempo, passado como compreensão mais profunda de si, futuro como nova possibilidade existencial, e presente como atitude a ser tomada em direção a uma imitação de Cristo, tal qual foi mencionado acima. O passado e o futuro delineiam o instante de apropriação do ato no qual se manifesta o instante do kairós em que a ocorre a passagem da realização do signo. Neste instante no ato da decisão em direção a Cristo, é o ato de Cristo que produz tal páscoa, e esse ato se dá na ação do Espírito, que é tornada consciente pelas Escrituras, bem como alimenta a vontade para esse momento ${ }^{24}$. Deste modo, a teologia dos quatro sentidos estão orientadas para essa passagem unitiva para com Deus e com seu povo, tornandose - um com Ele em Seu Espírito.

Tal movimento é fruto de uma theopoiésis, ou seja, de um modo de "Deus fazer" essa união acontecer, divinizando o homem, ou seja, do "tornar-se" ou "ser feito Deus" ${ }^{25}$. Esse tema já estava presente em Justino de Roma (cc 110dC), ao falar de Adão e Eva feitos como Deus, livre do sofrimento e da morte. O gênero humano antes da queda é livre dos tormentos da alma, vivem a apatheia tal qual é a natureza de Deus, de acordo com o "dogma" dos filósofos, apático e imortal. Voltar a ser "deus" para o homem, ou seja, livre do desespero e da morte, é possível

23. Ibidem, Secondie Partie - I, pp. 144-146.

24. Ibidem, p. 146.

25. Justino de Roma. Apologie II, 3,1. 
pela obediência aos mandamentos de Deus ${ }^{26}$.

Irineu de Lião (130-202dC) comentando a expressão "vós sóis deuses" ${ }^{27}$ da Septuaginta a respeito do uso de elohim no Salmo 82, faz menção ao batismo e a "graça da adoção", pelo qual se pode chamar Deus de Abba, Pai, e como filhos adotados no Filho recebem deste a incorruptibilidade e a imortalidade ${ }^{28}$.

\section{A theopoiésis da Teologia Alexandrina}

O primeiro autor a fazer uso da expressão theopoiésis é Clemente de Alexandria (150-215dC), que sofre uma forte influência de judaísmo helenista de Fílon (25aC-50dC), também da Alexandria. Para o judeu helenista, leitor da Septuaginta, a escolha do verbo poiéin ${ }^{29}$ indica a criação do nada e que contém a inspiração da imagem [eikon] e semelhança [homoiousios] de Deus que deve estar impressa na alma. Enquanto, pensador helênico a semelhança ${ }^{30}$ é o resultado da purificação da alma $^{31}$, porque a "sensação" [aisthésis] é "parente e irmã do pensamento", porém é "irracional"32, e Abraão em sua busca de atender ao chamado de $\mathrm{YHWH}$, inaugurando a trajetória em busca do Logos que é a Torah, a fim de que a alma não se perca em suas paixões e seus atos involuntários mas alcance a "verdadeira paixão"33 que é Deus. O modo como a alma vai se tornando amante da virtude é pelas migrações de sentido-imagem, do literal para o alegórico, pois sendo o profeta um "homem de visão", o asceta deve buscar a "imitação da imagem" 34 .

26. MOSSER, Carl. The earliest Patristic interpretations of Psalm 82, Journal of Theological Studies, NS, Vol. 56, Pt 1, April 2005, p. 38.

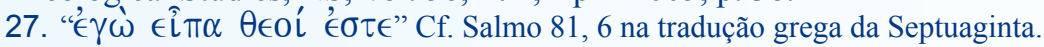

28. Irineu de Lyon, Contre les héresies, livre IV, I, 2.

29. Gn $1,26-27$

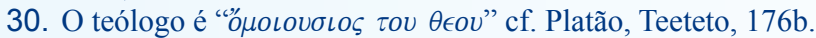

31. " $\psi v \chi \dot{\eta} \nu ~ \kappa \alpha \theta \eta \rho \alpha \iota "$ cf. Philon d'Alexandrie. La Migration d'Abraham, I, 1.

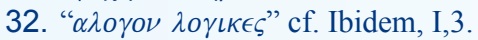

33. " $\alpha \lambda \dot{\eta} \theta \alpha \iota \pi \alpha \theta o ́ \varsigma$ " cf. Ibidem, VII, 225, 15.

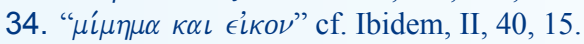


Clemente de Alexandria identifica na filosofia mosaica de Fílon quatro tipos de migrações que constituem a dialética da intenção da Torah, e como ela deve ser recebida, a saber, a história como "tipo" ou figura literária ${ }^{35}$ que contém a "epopéia do grande mistério"; as prescrições legais como "preceitos morais"; a liturgia entendida como preceito cerimonial e classificada como "signo" e a teologia como "profecia"36. Esses quatro sentidos constituem (tipo, preceitos morais, signo e profecia) identificados por Clemente, tenta conciliar a literatura bíblica e a tradição filosófica, entendendo que esta funciona como o antigo testamento dos pagãos, e ambas são preambula fidei, uma "ginástica preliminar"37 para a "verdadeira Filosofia", ou seja, a Teologia ${ }^{38}$. Contudo os filósofos gregos devem ser chamados de "ladrões", porque roubaram de Moisés, o estóico por excelência ${ }^{39}$, e dos profetas as idéias mais profundas, sem ao menos reconhecer tal influência. Se a importância da filosofia grega se dá porque preparou o mundo para conhecer o $\operatorname{Logos}^{40}$ é a filosofia mosaica que oferece uma dialética mais adequada, sendo Moisés mestre de Platão,

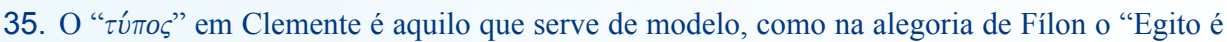

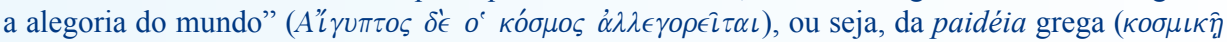

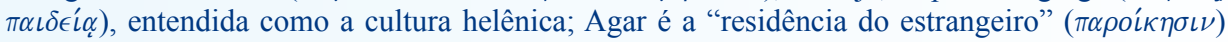
figura daquele que acolhe e ama a filosofia pagã; diferente de Sara que permanece fiel a Abraão;

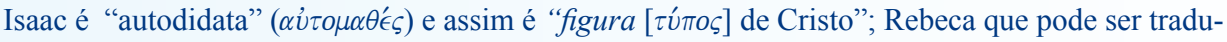
zida por "paciência". Cf. Stromata I, 30-32,4; 28,179,3.

36. Stromata I, 28, 179,3-4; cf. ainda De LUBAC, Ibidem, Premiére Partie - I, pp. 171-177

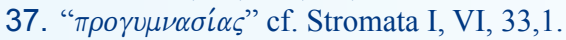

38. Stromata I, 2, 19-21; 13,58,1; V, 28-32.

39. O Moisés clementiniano segue a tipologia de Fílon, como modelo de estóico: profeta, legislador, tático, estrategista político e filósofo. O modo como Fílon em Vida de Moisés apresenta o

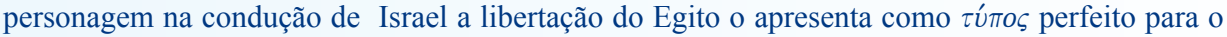
futuro modelo de grego, inspirador da política de Platão, marcada de virtudes cívicas e mestre na dialética. Stromata I, 23,151,1-179,4.

40. Stromata V, I, 10,1. Por exemplo a "criação pitagórica" de que a matéria original foi moldada pelo melhor operário (demiurgo) tendo a si mesmo por arquétipo é um plágio da sentença bíblica de que "Deus criou o homem à sua imagem e semelhança"; bem como a recomendação de evitar a idolatria e noção de justiça de "não ultrapassar o jugo" afim de que "não transgrida a igualdade na distribuição de honra e justiça”. Cf. Stromata V, 5, 29,2; 5,30,1. Também acusa Platão do mesmo plágio cf. Pedagogo II, 10,9,2; 100,4. 
para captar a "força de Deus" 41 cativando 42 para conhecer a "vontade da Lei”, que permite a purificação de todas as paixões. Assim o sentido literal ou tipológico da Lei apenas carrega modelos, porém se entender a dialética como "capacidade de discernimento" ${ }^{43}$ para a "formação da consciência a fim de "distinguir" 44 as "confusões" 45 , e classificar as coisas em princípios ou gêneros que permitam assim na medida em que toma consciência e passa a desejar a "vontade da Lei", essa "força permeia as atitudes" ${ }^{\prime 4}$ sendo "gerada nesse exercício de discernimento" ${ }^{47}$, e assim se "manifesta" 48 a "integridade" [onton katharon] ${ }^{49}$. Por isso, além do modelo, para aquele que busca na filosofia mosaica também a purificação das paixões para unir a própria vontade à vontade da Lei, ora encontra um "sinal" ( $\sigma \eta \mu \epsilon \hat{\imath} o \nu)$ que ilumina a própria alma na busca de distinguir as confusões; ora encontra uma "ordem" (' $\epsilon \tau \tau \partial \lambda \dot{\eta} \nu)$ para se fazer o que é "certo" ( $o \rho \theta \eta \nu)$ entre as possibilidades todas; e ora encontra a inspiração de uma "profecia" ( $\pi \rho \circ \phi \eta \epsilon \in \alpha \nu)$ e assim se pode extrair melhor o "ensinamento divino" ${ }^{" 50}$ das Escrituras.

Clemente não explica como teria sido essa influência e nem como Pitágoras (século VI aC) e Platão (428 a 347aC) teriam acesso à

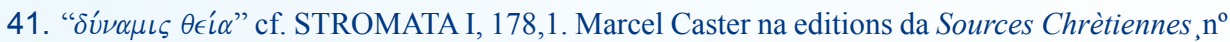
30 de 1951, optou por traduzir como "faculté divine", parece apresentar um pressuposto racionalista de que então a razão ao tomar consciência das paixões, permite a posse da "perfeição" e "purificação" das mesmas, contudo mantemos em nossa opção de tradução a opinião de que o racionalismo em que o logos é identificado com uma espécie de "raciocinar divino" é um pressuposto insuficiente para leitura do fenômeno da dialética patrística. cf. Ibidem, p. 174: "une faculté divine, qui connait les êtres dans ler être et possède la perfection, car ele est dégagée de toute passion".

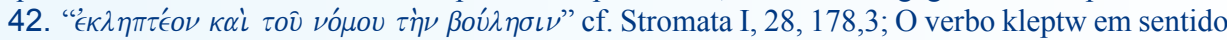
concreto é usado para "roubar" utilizado pelo $\kappa \lambda \epsilon \pi \tau \iota \kappa o ́ \varsigma$ (ladrão). Em sentido figurado é usado para "cativar o entendimento" ou ainda "apoderar-se por surpresa”. Cf. PEREIRA, Isidoro. Dicionário Grego-Português/Português-Grego. Coimbra: Gráfica de Coimbra, [s.d.], verbete, $\kappa \lambda \epsilon \pi \tau \omega$. A edição da Sources Chrètiennes traduz por "recevoir".

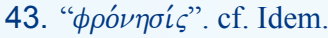

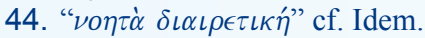

45. " $\alpha \mu i ́ \kappa \tau \omega \varsigma "$. cf. Idem.

46. “" $\delta \dot{\nu} \nu \alpha \mu \iota \varsigma \pi \epsilon \rho \dot{\iota} \tau \dot{\alpha} \tau \hat{\omega} \nu \pi \tau \alpha \gamma \mu \alpha \dot{\tau} \tau \omega \nu$ ” $\mathrm{cf}$. Idem.

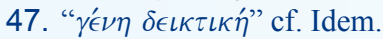

48. " $\phi \alpha \iota \iota \epsilon \sigma \theta \alpha \iota "$ cf. Idem.

49. " " $\nu \tau \omega \nu \kappa \alpha \theta \alpha \rho \dot{\nu} \nu$ " cf. Idem.

50. " $\theta \epsilon i \alpha \varsigma \delta\llcorner\delta \alpha \sigma \kappa \alpha \lambda i \alpha \varsigma$ " cf. Idem. 
Septuaginta que tem a primeira versão composta somente no reinado de Ptolomeu II, no Egito entre 305 a $285 a^{51}$. Entretanto com isso, a alegoria alexandrina, defende o direito de cidadania e legitimidade epistemológica, da filosofia cristã para com a filosofia grega a partir da filosofia mosaica, para que possa então mostrar a "verdade mais adequada"

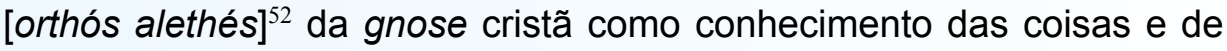
Deus, e daquelas melhor conhece por conhecer seu Criador, e por isso a gnose cristã é capaz de melhor entender a "ordem do mundo" ${ }^{33}$ revelada pelo Logos que se fez carne e Pedagogo ${ }^{54}$ para conduzir a "vida perfeita" e "imortal" acolhendo a graça da "uiopoiésis", de "ser feito filho"55 e assumir o modo de vida do Filho e colaborar com a ordem do mundo desejada por Deus. A theopoiésis atua como pró-vidência, ou seja, em prol da consciência [pró-nous] a fim de que possa discernir a ação do $\operatorname{Logos}^{56}$ e assim ser conduzida a alma, pelo modo que "inspira" a pensar e agir, a união com Deus. Essa é a visão, bastante influenciada pelo estoicismo, que Clemente irá demonstrar na tapeçaria (stromata) de autores e proposições filosóficas de que a gnose cristã é a verdadeira filosofia a ser seguida, porque a vive em maior profundidade ainda, o que se iniciou nas duas outras escolas.

Essa theopoiésis é "universal" quada para se assimilar a vontade de Deus, antes manifesta imperfeitamente na Lei, e agora de modo perfeito na vida [perfeita] de Cristo, como aquela que é portadora do teleios ${ }^{58}$ de Deus, ou seja, a vida de Cristo realiza a finalidade da criação. Em Clemente, a vida cristã é o modo

51. SPINELLI, Miguel. Helenização e Recriação de Sentidos, pp. 63-78.

52. Sobre a demonstração das proposições da gnose da fé $[\gamma \nu \omega \sigma \iota \varsigma]$ ou a filosofia cristã em relação

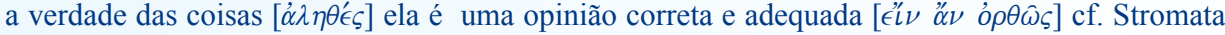
II, 9, 49,4.

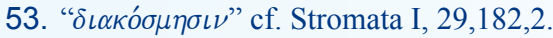

54. Pedagogo I, 4, 1-2.

55. "viотоьои́ $\mu \in \alpha$ "cf. Pedagogo I, 6, 26,1.

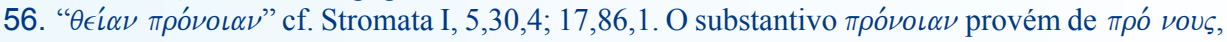
o que age em favor da consciência da verdade.

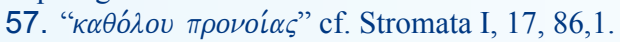

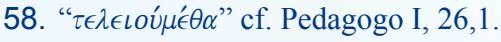


mais profundo que se realiza o ideal de perfeição dos estóicos, porque é a theopoiésis, ou seja, o agir de Deus que conduz a alma à perfeição devido a uiopoiésis que o Pedagogo conduz, por ser Ele o Filho de Deus. Portanto, o caminho da vida perfeita, ideal de época, acontece na uiopoiésis do batismo, como graça que deixa a marca [charisma] ${ }^{59}$ da ação de Deus, ou seja, a theopoiésis. O batismo carrega não somente a graça da vida perfeita, mas a proposta da vida cristã, que na medida em que a vive, se é "iluminado" na consciência de ser "adotados como filhos" de Deus, e portanto, redestinado para alcançar a "vida que não acaba"60:

"[...] batizados, nós somos iluminados; iluminados nós somos adotados como filhos [ui'opoiou,meqa]; adotados somos feitos perfeitos; e tornados perfeitos, nós recebemos a vida que não acaba [...] Este trabalho [de Deus] recebe muitos nomes: graça, iluminação, perfeição, banho. Banho, pelo qual nós somos purificados de nossos pecados; graça, pela qual aquelas condenações merecidas por nossos pecados são removidas; iluminação, na qual nós contemplamos a imagem santa, luz salvífica do olhar penetrante de Deus; perfeito por não faltar nada".

O batismo enquanto banho diz respeito ao acolher o caminho que é possível por descobrir-se perdoado por Deus, a graça é o convite para "ser feito deus", tal qual o filho. Mas quem pode ser chamado assim, como alguém divinizado (theopoeta)? Para Clemente são aqueles que são "mais fortes que os desejos, que vencem suas paixões, aqueles que têm a direção de todos os seus atos, os gnósticos, aqueles que são maiores que o mundo". Esses são "deuses" (theoi) e "filhos do Altíssimo" (uioi upsistou) ${ }^{61}$.

A definição de filiação divina do filósofo alexandrino, permanece bastante estóica, pois contempla a ausência das paixões e ausência da morte, e esta vinculada àquela. Assim o banho e a graça constituem o início

59. " $\chi \alpha \rho \iota \sigma \mu \alpha "$ cf. idem.

60. " $\alpha \pi \alpha \theta \alpha \nu \alpha \tau \iota \zeta \zeta^{\prime} \mu \epsilon \theta \alpha$ " cf. idem.

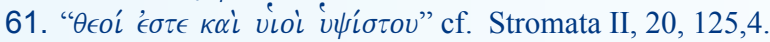


da "pedagogia" da theopoiésis que é a "religião"62 e se desdobra na busca da iluminação como indicação da verdade pela via da "contemplação de Deus" e da sua "ações santas" da em uma "perseverança eterna" que constitui a perfeição ${ }^{63}$ que não separa o conhecimento (gnose) da sabedoria nem a práxis da justiça (dikaiopragia $)^{64}$. Deste modo a iluminação e a perfeição se implicam mutuamente na gnose clementiana, sendo a agapé o seu fundamento ${ }^{65}$.

Diante então procura de sabedoria e justiça o gnóstico deve contar com a providência (pronoian) para iluminar seu modo de pensar e agir, buscando o "discernimento" (dianoia) do sentido (logos) inspirado pela theopoiésis, e que é percebido como experiência "estética" (aisthésis) ${ }^{66}$ do Logos escondido nas Escrituras que permite se afastar a vontade das paixões, e participar da energia de Deus rumo ao Logos em sua lógica de filiação.

Essa iluminação visa então a purificação das paixões (pathos) que se dá pela depuração das imagens que representam os desejos humanos, a saber sua fantasia ${ }^{67}$. Em Clemente o pathos é "sem sentido" (alogos) ${ }^{68}$ e necessita de imagens para "conhecer a si mesmo" ${ }^{19}$ a fim de Ihe oferecer um logos a respeito de si, contudo, o ser humano é vulnerável em sua capacidade humana de ser afetado (pathos) pela realidade provocando-lhe desejos com a "ilusão" de satisfação a "todo tempo e sem limites"70. Essa ilusão "tipifica" na alma uma "fantasia" que a repre-

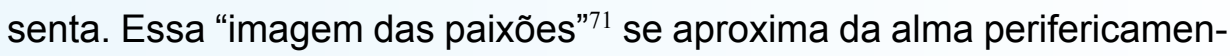

62. " $\theta \epsilon о \sigma \epsilon ́ \beta \epsilon \iota \alpha "$ cf. Pedagogo I, 7, 53,3.

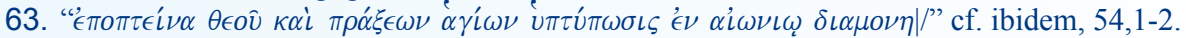

64. Stromata II, $10,47,4$.

65. Ibidem, 30,3-31,1.

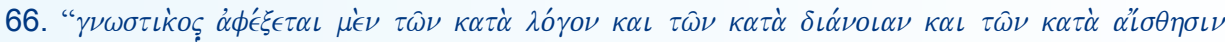

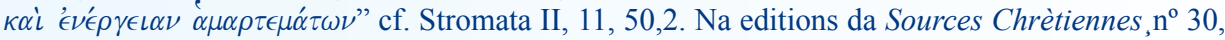
Caster opta por "sentido espiritual" a tradução de $\alpha$ ¿ $\sigma \theta \eta \sigma \iota \varsigma$.

67. Ibidem, 20,111,4.

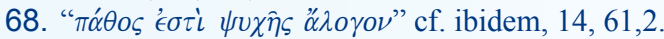

69. " $\gamma \nu \hat{\omega} \theta \iota$ $\sigma \alpha \nu \tau \tau^{\prime} \nu$ "cf. Ibidem, 15, 70,5

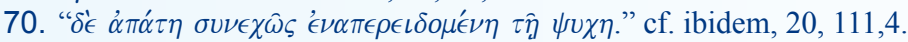

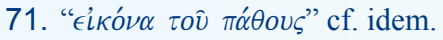


te, e assim se esquiva da atenção da consciência até seduzi-lá para o consentimento, e assim provocam um "distanciamento" da verdade ${ }^{72}$.

Sem a depuração das paixões a vontade apaixonada por sua fantasia é mais forte que as resoluções sensatas ${ }^{73}$, por isso a gnose clementiniana fala do "discernimento das fantasias" $"$ e dos movimentos provocados na alma ${ }^{75}$. Deste modo implica na gnose do batismo a apreensão da Logos "iluminador"76 que por meio das inúmeras imagens da literatura neotestamentária ${ }^{77}$ pelo qual vai se assimilando a sabedoria de Jesus ${ }^{78}$ que se manifesta de múltiplas e infinitas formas, pela arte, ciência, fé, profecia $^{79}$, porém de modo especial há que se fazer a "experiência [sensível] de Deus" ${ }^{80}$ que se distingue do sentido intelectual, se manifestando como uma "experiência do Espírito" 81 que permite acolher o e perceber acolhido como em uma experiência de encontro (sinaisthesis) ${ }^{82}$ que desperta a veneração para o amor de Deus, de modo que "a gnose consumando-se no amor, se aproxima o cognoscente do conhecido, como um amigo a outro amigo. E sem dúvida, tal homem, deste modo, alcance um ser igual ao dos anjos"83. Assim a alegoria conduz à experiência de contemplação das imagens do Evangelho, e "exercitadas" ${ }^{44}$ produzem a "docilidade da escuta" da Palavra em que o modo de se fazer "presen-

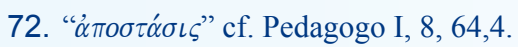

73. Stromata II, $15,63,2$.

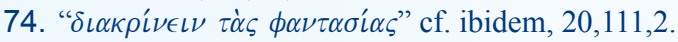

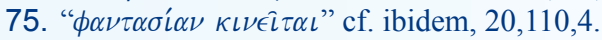

76. " $\phi \omega \tau i \zeta \omega \nu ”$ cf. ibidem, 15,66,1.

77. Clemente é o autor da patrística de sua época que mais faz uso da literatura neotestamentária. Enquanto Ireneu cita 865 passagens do Novo Testamento; Hipolito 259; Orígenes 934, Clemente faz uso do Novo Testamento 1608 vezes. Cf. COSAERT, Carl. The Text of the Gospel in Clement of Alexandria, p. 2.

78. "I $\eta \sigma o \hat{v} \sigma o \phi i \alpha "$ cf. Stromata I, 4,27,1.

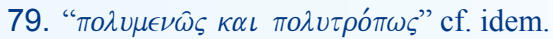

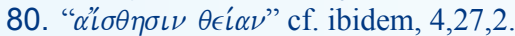

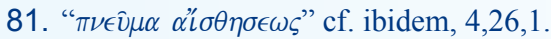

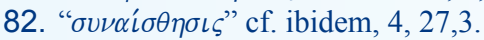

83. Stromata VII, 10,57,4-5.

84. " $\sigma \nu \nu \alpha \sigma \kappa \dot{\eta} \sigma \epsilon \omega o \varsigma$ " cf. Stromata II, 6,26,4. 
te" de Deus é por meio da inspiração ${ }^{85}$ da imagem que desvela Alguém que "ama intensa e ternamente" ${ }^{86}$ em que ocorre uma identificação dos "mesmos sentimentos" se torna "imitador" 89 do sentido destas imagens e passa a "cooperar" com a inspiração da theopoiésis por meio da iluminação que se vai lhe produzindo.

Assim no "exercício" efetivo porque afetivo da contemplação das alegorias, vai se depurando a verdadeira imagem a ser seguida e se alcança a virtude da apatheia ${ }^{92}$ que permite a liberdade afetiva diante dos apelos interiores integrados com o Logos para adquirir a capacidade de se decidir pelo correto ${ }^{93}$. Sem a liberdade da apatia a fantasia das paixões é mais forte que as resoluções. O ser humano é marcado pela "necessidade" e pela "ignorância" 94 e não exercitado na apatia é passível de "atos involuntários" 95 e irracionais fruto da alma que vulnerável ao sofrimento, a necessidade e marcada pela ignorância é seduzida pelas paixões que o escravizam.

A apatheia é uma virtude estóica que é bastante influente no pensamento alexandrino ${ }^{96}$, e é ela que acolhe a theopoiésis. É difícil precisar se a apreensão de Clemente a respeito da apatheia é a mesma dos estócios, pois para o filósofo cristão grego, a diferença entre Cristianismo e estoicismo, é que aquele realiza melhor o ideal deste, pois a vida é

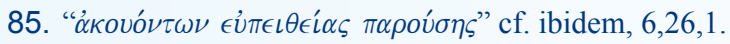

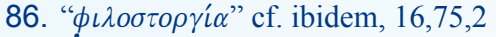

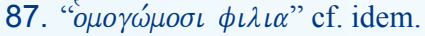

88. " $\pi \alpha \rho \alpha \delta o \chi \hat{\eta} \varsigma "$ cf. ibidem, $6,26,1$.

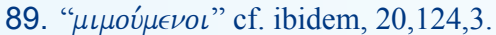

90. " $\sigma \nu \nu \epsilon \rho \gamma \in \hat{\imath} "$ cf. idem.

91. " $\sigma \nu \gamma \gamma \mu \alpha \sigma i \alpha \mid$ " cf. ibidem, 20,122,1.

92. Ibidem, 20,103,1.

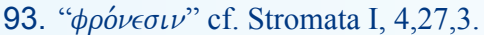

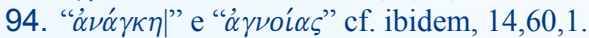

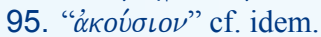

96. Atanásio da Alexandria chega a dizer que no pecado de Adão é que nascem as paixões, e que é o abandono a elas que faz nascer o pecado, e a idolatria. Cf. Athanase d' Alexandrie. Contre les Païens, I, 3; 4;7-9. 
igualmente marcada pela continência ${ }^{97}$, leis, eliminação de desejos, e superação das paixões, contudo, fato é que a apatheia cristã é fruto da amizade com Deus ${ }^{98}$, como efeito do "amor que permanece no amado" 99 e assim passa a enxergar com os olhos de Deus, e a se conhecer como "imitador de Deus"100, não somente sua "imagem", mas também sua "semelhança" ${ }^{101}$, ou seja, capaz de agapé: "Viste o teu irmão, viste o teu Deus" 102 .

O teopoeta ${ }^{103}$ em Clemente de Alexandria é aquele que cresceu na amizade com Deus e alcançou a apatia, tornando-se unido a Deus em que âncora a existência em meio às tempestades das paixões. Ele não é arrastado pelas ilusões, mas antes atrai a presença de Deus colaborando com sua Providência.

A theopoiesis exige uma discussão a respeito da ortho-imagem que se verifica na ortopraxia, como se evidência na crítica de Clemente a Basilides, de entender a alma na imagem mito-poética do "cavalo de Tróia", em que ela mesmo conteria toda a origem das desordens das paixões, com um certo pessimismo, o que impede a sunergeia. A autêntica imagem acolhe a theopoiésis e conduz para a liberdade e para o amor ao outro, ao passo que as fantasias conduzem a alma para a escravidão, e centramento em si.

\section{A poiésis da Teologia Capadócia}

$\mathrm{Na}$ teologia capadócia o tema da divinização do ser humano sofrerá uma mudança terminológica para o mesmo substrato semântico, em que se prefere o uso de theósis, ligado também a participação e um

97. "' $\nu \kappa \rho \alpha \dot{\alpha \epsilon \iota \alpha \nu ” ~ c f . ~ S t r o m a t a ~ I I, ~ 20,105,1 . ~}$

98. Ibidem, 16,75,2.

99. Ibidem, Patres Ecclesiae, p. 135.

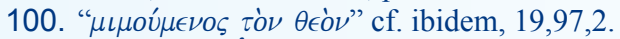

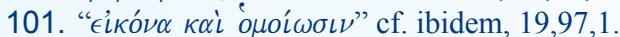

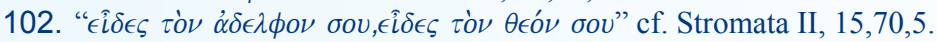

103. Stromata IV, 23, 317. 
progresso moral. Tal questão implica uma depuração do pathos, porém não como na apatheia alexandrina, mas sim na participação no pathos de Cristo. Gregório de Nissa (330 a 395dC) apresenta uma antropologia marcada pelo princípio da morte e pelo princípio da ressurreição, porém com a encarnação do Logos a paixão humana marcada pelo sofrimento é agraciada com a paixão de Deus marcada pela esperança da vida nova [que une o corpo e alma para sempre] pois o pathos do protótipo humano foi criado em vista do pathos do arquétipo da imagem crística, ou seja, o pathos humano existe porque há um pathos em Cristo, pois é o humano a imagem de Cristo e não este a imagem daquele ${ }^{104}$.

Tal perspectiva também está presente no Gregório de Nazianzo (329 a 389dC), em que a theosis acontece na participação do pathos de Cristo. Contudo se Gregório não faz uso da expressão theopoiésis, talvez para não ser confundido com a teologia alexandrina, o teólogo de Nazianzo, por sua vez, no último ano de sua vida poetiza de fato, a theosis de Christo. Esta acontece como resultado do batismo como caminho para o conhecimento de Deus no qual se inicia a busca da iluminação [fothismós] ${ }^{105}$ da consciência e da purificação [katharótes] ${ }^{106}$ das atitudes [praxia] e disposição interna para elas [pathos], pois o batismo não se reduz a um rito, mas enquanto experiência de um caminho deixa sua marca [grammata] afetiva profunda que opera como traço da própria pessoa [charaktér], pois o batismo enquanto caminho mistagógico visa atingir a verdadeira imagem [eikona] de Deus. Essa iluminação e purificação são realizadas pelo labor divino [theourgia] que é aco-

104. NYSSENUS, Gregorius. In Scripturae verba, Faciamus hominem ad imaginem et similitudinem nostram. XVI, 5 (PG 44, 175-188); La Gran Catequesis, pp.95-99 (PG 44, XVI,1-8)

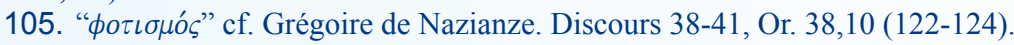

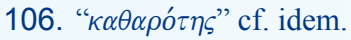


Ihido pelo exercício da contemplação [theoria] e assim ocorre a comunhão com Deus, como participação do Mistério que resulta na alma humana como uma nova mistura [miktos] de naturezas, onde se participa da "mente da Trindade"107 não no sentido de compreender totalmente o Mistério, mas em uma "fusão paradoxal" que permite olhar a realidade com os olhos de Deus, ainda que por um instante, porém de tal modo que o olhar nunca mais volta ser o mesmo, pois na theoria teológica do nazianzeno, ou seja, a contemplação, não está restrita a uma perspectiva meramente inteligível (noetós) ${ }^{108}$, mas fundamentalmente sensível (aisthetós) ${ }^{109}$, enquanto experimenta aquilo que entende, sobretudo a amizade de Deus, em que o teólogo é um filo-Cristo ${ }^{110}$. A inspiração para esse entendimento se dá por oferecer uma imagem de Deus [eikón theou $]^{111}$ que corresponda ao sentido experienciado, e permita a imitação deste sentido, pois a inspiração interior permite a disponibilidade exterior. A “inspiração” é obra do Espírito ${ }^{112}$.

A poesia de Gregório de Nazianzo, conhecido como "O Teólogo" é mediadora da contemplação como processo cognoscitivo de si e de Deus. Compôs sua Carmina em dois livros ${ }^{113}$ a saber, a poemata theologica subdividido em poemata dogmática (Princípios, Trindade, Espírito Santo, Inteligências celestes, O Mundo, A Providência, A Alma) e moralia (iluminação e purificação da alma) e o outro a poemata histórica (Os Patriarcas, As pragas do Egito, Moisés e a Lei, a Vinda de Cristo, Sua Genealogia, seus Milagres, suas Parábolas, os

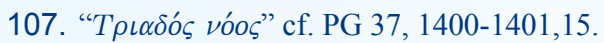

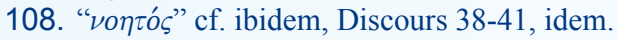

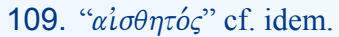

110. CARVALHO, Margarida Maria de. Paideia e Retórica no séc. IV d.C, p. 80.

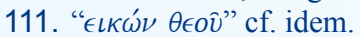

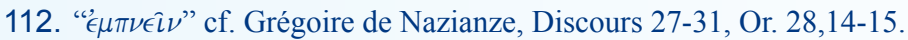

113. GREGORII THEOLOGI. Poemata In Patrologia Graeca 37, Tomus Tertius;

Poemata In Patrologia Graeca 38 - Tomus Quartus 
doze apóstolos) e termina com um Hino a Deus.

Sua poiésis está a serviço da theoria, a fim de que alcance o sentido anagógico, a partir da restauração da imagem divina, que permite a releitura da imagem de si [iluminação e depuração], imagem de Deus, inaugurando o processo de metanoia ${ }^{114}$, como mímesis de Cristo, o archétipos do ser humano no qual vai gerando ações catársicas que inclinar os movimentos internos para o amor de Deus ${ }^{115}$, que vão emergindo da theósis como uma "conversa mais pura com Deus". O gênio poético de Gregório convida a uma poesia intima da natureza humana como pergunta de "quem eu sou?" apalpando as paredes cegas das próprias certezas, fazendo acordar para si mesmo como descoberta intíma, em que a luz da poesia altera a cor e o movimento das coisas como ao atingir uma beleza mais profunda ${ }^{116}$, resulta em um desencanto do mundo, daquilo que não permite enxergar a luz de Cristo, desejando outra vida. Entretanto, a poesia é o remédio da dor, o caminho da consolação ${ }^{117}$ que capta a inspiração divina e o insere na participação da epopéia divina, da paixão à ressurreição.

Enquanto arquétipo, "Cristo está inscrito no íntimo"118 do ser humano, de modo que a poesia expressa o que está impresso, por isso é a profundidade da poesia que eleva o sentido do dogma ${ }^{119}$ e se torna um catecismo que se pode aprender pelo coração ${ }^{120}$ através do sinais sensíveis que a narrativa da poesia fala na linguagem dos homens

114. KALLERES, Dayna. Demons and Divine Illumination: A Consideration of Eight Prayers by Gregory of Nazianzus p. 174.

115. Grégoire de Nazianze, Discours 1-3, Or. 1, 4 (76).

116. Carmina de vita sua, II,1828-1855 (PG 37, 1157-1159).

117. Carmina, 2,1,34,19-24 In Gregorius Theologus Opera Omnia. PG 37, 1308-1309.

118. Ibidem, Discours 38-41, Or. 40,10; 15; 35; 37 (216-218; 228;278; 282).

119. GRENIER, A. La Vie et le Poésies de Saint Gregoire de Nazianze, p. 130

120. Ibidem, p. 131. 
e por meio do qual o Espírito Santo se faz conhecer ${ }^{121}$, sendo assim a poesia gregoriana uma "escola de eternidade" ${ }^{22}$, ao passo que a heresia desfiguram a beleza do dogma.

O essencial da poesia do teólogo capadócio não é a métrica ou a harmonia, mas o movimento de ousadia e novidade, por não se restringir à fórmula teológica, mas ao elemento material da experiência do qual emerge a fórmula, sendo a sua composição "sob os olhos" a fim de oferecer a contemplação do movimento pneumático, pois o Espírito é o centro de todos os movimentos.

Entretanto a mente humana não é capaz de manter mais que um instante momentâneo a imagem divina, de modo que se Gregório adota a cosmologia platônica de participação ${ }^{123}$ para apreensão do Mistério, a sua "eficácia epistemológica" se radica na epistemologia estóica enquanto a iluminação do modo de pensar, que inspira a precisão da linguagem também deve oferecer novas ênfases nas atitudes que melhor imitam as "impressões" 124 do amor de Deus. É a práxis a empiria do pathos e a norma do logos.

De modo que o conhecimento de Deus passa por uma primeira depuração do hegemonikon discernindo quais imagens correspondem ao movimento do Espírito que aponta para a profundidade do pensar e do agir, e quais imagens são fantasias que desejam conduzir a Deus de modo precipitado e incorretamente. Tais imagens de fantasia são "demônios" que atuam como "mestres do erro", "ambíguas", "tipos errôneos"125 igualmente com "falsas opiniões e impressões fantasiosas"126.

121. Ibidem, p. 160.

122. Ibidem, p. 167.

123. IGLESIAS, Maura. A relação entre sensivel e inteligivel: methexis ou mimesis? In PERINE, Marcelo (org.) Estudos Platônicos - Sobre o ser e o aparecer, o belo e o bem, pp. 91-112.

124. "' $\epsilon \mu \phi \dot{\alpha} \sigma \epsilon \iota \varsigma^{\prime}$ cf. ibidem, Discours 1-3, Or.2,7 (96).

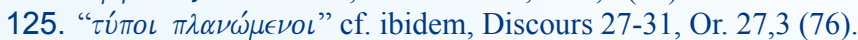

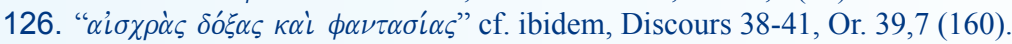


No entanto, a iluminação do pensar e a depuração do agir enquanto é insuficiente para discernir a origem dos pensamentos correndo o risco de que as coisas consideráveis sejam negligentemente esquecidas ao passo que as coisas insignificantes incorrem no risco de serem laboriosamente esgotadas ${ }^{127}$. Deste modo, diferente da apatheia alexandrina que julga que a liberdade dos afetos é que permite o logos captar a theopoiésis, o caminho mistagógico batismal é fruto da imitação do Christós paschoé ou ainda como ficou conhecido na forma latina, Christus patiens, em que o pathos humano vai assimilando o sotérion pathos de Cristo ${ }^{128}$.

A radical diferenciação da teologia capadócia em relação a apatheia alexandrina fica patente na tragédia gregoriana, que convida o espectador deste espetáculo teatral a apreender o mistikon logon narrado pela própria mãe do Cristo e daquele que é querido ao coração do Mestre, chamado de theólogos ${ }^{129}$.

A tragédia é apresentada como "atração da árvore" 130 que denota a condição humana implicada na questão de "Adão, o pai de todo o gênero humano"131 da imagem de Deus apática e a inimizade advinda dessa imagem e a fragilidade humana diante do sofrimento, de modo especial do sofrimento de uma mãe diante da morte injusta de um filho justo e nascido de uma ação miraculosa de Deus. A Maria de Gregório Nazianzeno não é uma estóica, mas é apresentada com as cores e contornos de uma mãe humana ${ }^{132}$, apesar de ser chamada de Theotókos durante toda a obra. Maria

127. Ibidem, La vie et la poesie..., p. 208

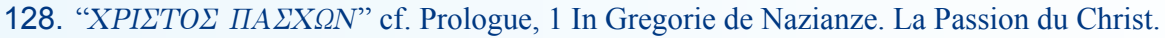

129. " $\mu \iota \sigma \tau \iota \kappa \omega \nu \nu \lambda o ́ \gamma \omega \nu "$ cf. ibidem, 5.

130. "' $\rho \nu o v \varsigma " ~ € \rho \omega \tau \iota "$ cf. idem.

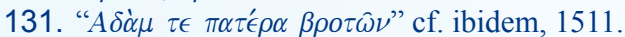

132. Grein julga que a Tragédia pascal vivida por Maria com perspectivas humanas profundas é uma "odieuse profanation" por contrariar mentalidade de Maria como modelo extraordinário de paciência. Cf. ibidem, La Vie et les Poésies, pp. 251-252. 
esconjura Judas e o chama de "aquele que profana a amizade"133; seu coração desfalece ${ }^{134}$ e as palavras todas são confusas ${ }^{135}$ a dor é "mais forte" que suas "certezas"136. Também a "extraordinária beleza" se perdeu ${ }^{137}$.

O teólogo recorda que o Cristo aceitou livremente o seu caminho, e que Deus de uma maneira maravilhosa renovará dessa verdadeira "tristeza" 138 pelo poder do Criador que "sofre por suas criaturas"139 e assim permanece os dois confiantes naquele que tudo pode, no "Deus inesperado"140 e "imprevisível"141. A cruz é apenas um "estranho eclipse do sol"142 e a luz brilhante do dia se manifesta silenciosamente ${ }^{143}$ e penetra ao fundo dos corações angustiados ${ }^{144}$ agraciando com a plenitude do espírito e alegria imen$\mathrm{sa}^{145}$ para se entoar um cântico de vitória ${ }^{146}$. Essa vitória permite a confiança de ser instruído por Deus mesmo, na intimidade agora purificada e iluminada: "Eu sou tua criatura, instrui-me, oh Logos, corrige-me tu mesmo aqui em baixo"147.

A gnose gregoriana, ao invés da apatheia passa por uma patodicéia, por um responder àquilo que faz sofrer, descobrindo nessa

133. Ibidem, 345 .

134. Ibidem, 465.

135. Ibidem, 615.

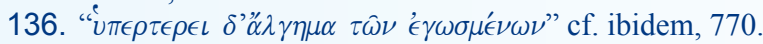

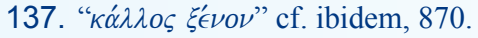

138. " $\lambda u \pi \rho \dot{\alpha} "$ cf. ibidem, 960.

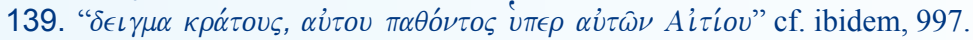

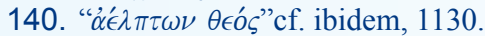

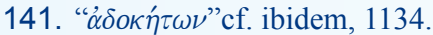

142. Ibidem, 1205.

143. Ibidem, 1919.

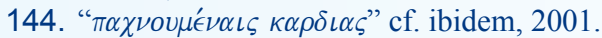

145. Ibidem, 2113.

146. Ibidem, 2519.

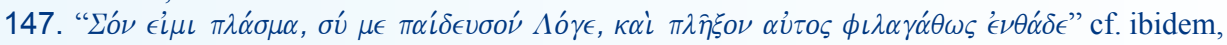
2554-2555. 
"busca sincera"148 para dentro de si a própria presença de Deus como luz que penetra toda dor.

O pathos é a dimensão da manifestação do "coração angustiado" (kardias pachoumenés) ${ }^{149}$ que busca a luz de Deus em meio as trevas de sua dor. A angústia, doença da alma supõe já um homem novo, contudo que recebeu de outro a revelação e não provém da própria experiência. $\mathrm{O}$ abatimento advém da insuficiência das ilusões e das forças primeiras ${ }^{150}$. A dor pode ser caminho para regenerar a própria alma onde se efetuará a aprendizagem e se perpetuará o sentido de seu destino e a fecundidade do mesmo. A angústia emerge do fundo da alma, da imagem do mundo divino que se esvai como "efeito vago e estéril instinto de imortalidade"151. Há uma influência do Eclesiástico no qual a dor da existência contagia a apatia.

Faz-se necessário o silêncio ${ }^{152}$ de onde brota a angústia como "efusão involuntária" e "linguagem espontânea do coração", pois no "ser humano palpita humanidade" e desejo de vida que encontra no Cristo a mais profunda humanidade arquetípica, que por sua densidade se constitui como imagem que não pode ser explicada (eikon agrafós) ${ }^{153}$. Há uma influência da literatura sapiencial do Eclesiástico em que a inquietação existencial contagia toda a possibilidade da apatia ${ }^{154}$ e a poesia permite aflorar a consciência da experiência de si. Por isso a poética gregoriana explora desde a imagem satírica até a melancolia, como manifestação do coração humano.

Há patodicéia gregoriana, provocada pela poesia do Christus patiens que permite assumir a condição de homo patiens a fim de alcançar

148. "ó $\theta \hat{\omega} \varsigma \lambda{ }^{\prime} \gamma o \iota \varsigma "$ cf. ibidem, 2340.

149. "к $\alpha \rho\left\llcorner\alpha \varsigma \pi \alpha \chi \nu o u \mu \mu^{\prime} \nu \eta \varsigma " \mathrm{cf}\right.$. ibidem, 1819.

150. Ibidem, La Vie et les Poésies..., p. 210

151. Ibidem, La Passion du Christe, 1819.

152. STORIN, Bradley. In a Silent Way: Ascetism and Literature in the Rehabilitation of Gregory of Nazianzus In Journal of Early Christian Studies, pp. 225-257; Carmina, 2,1,34,149-150.

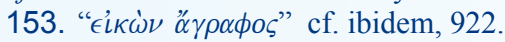

154. Ibidem, La vie et Les Poésies..., p. 159; 222. 
a "bela serenidade, do amor gratuito [agapé] e da amizade, a via da meditação e da sabedoria que mantém a resiliência que não se abala" ${ }^{155}$. Assim, a divinização em Gregório tem como efeito, não a apatheia alexandrina, mas hesichia, ou seja, a serenidade que emerge da amizade crescente em Deus que se ocupa do sofrimento humano e em meio a Ele manifesta a via da suprema beleza, imagem que ninguém pode explicar ${ }^{156}$ como um sentimento sólido da presença de Deus que tudo pode e que triunfa na angústia ${ }^{157}$. É assim que o cristão "será como deus"158, cristificado ${ }^{159}$, tornado filho em seu modo de pensar e ser. O dogma é portador de beleza de Deus, e a poiésis é sua via de acesso, na medida em que provoca a identificação ao desejo da vontade de Deus, vontade de beleza para suas criaturas. Em Gregório pode se pensar que a contemplação [theoria] é mesma fonte para a teologia e a poesia, e ambas estão a serviço de uma paidéia cristã ${ }^{\square}$

\section{Conclusão}

A ideia de poesia no Cristianismo patrístico é correlata à imagem que permite uma experiência estética como Mistério de Deus, de modo que a alegoria e a tropologia são caminhos para a anagogia, para o sentido unitivo de comunhão de vontades, tema esse que tem em seu substrato semântico a ideia de divinização, theósis na teologia capadócia, e theopoiésis na teologia alexandrina. Ambas implicam pensar um caminho para essa comunhão que é provocada pelo próprio Deus, mas que se pede a adesão livre de um convite, o que faz com que o caminho para a divinização seja primeiramente o caminho para a liberdade, buscando maior clareza de si e do caminho, bem como depurando as fantasias que

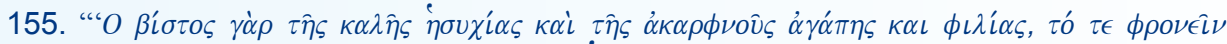

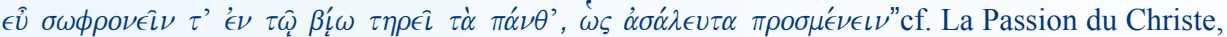
1800-1804.

156. Ibidem, 923.

157. Ibidem, 982; 1128.

158. " $\theta \epsilon \dot{\omega} \nu \phi \alpha \nu^{\prime} \in \tau \tau \alpha$ " cf. ibidem, 1758.

159. Ibidem, In Silent Way, p. 246. 
desfiguram a realidade, e consequentemente, a beleza de Deus presente nela.

A theopoiésis clementiniana se consolida na teologia alexandrina, sendo seguida não só por Orígenes, discípulo mais próximo de Clemente, mas segue o curso do pensamento como em Atanásio (c.295 a 373dC) no seu combate ao arianismo, em que a theopoiésis da humanidade de Cristo diz respeito a Sua exaltação, ou seja, a divinização do humanidade assumida em Cristo ${ }^{160}$. A theopoiésis não somente inspira a uma imitação de semelhança (homoiousios) mas insere o ser humano na participação da mesma natureza divina (homouousios), pois a Encarnação é a theopoiésis do Pai que ao exaltar a humanidade do Filho, adota toda humanidade. A theopoiésis do Filho torna-se theopoiésis da humanidade como iluminação, vivificação e herança da vida que não acaba. Aliás o "objeto" da Encarnação é a theopoiésis do ser humano pela partilha do Espírito de Cristo ${ }^{161}$. Cirilo de Alexandria (c.375 a 444dC) irá explorar a theopoiésis que acontece na ministração do mistérion, ou seja, dos sacramentos, especialmente na Eucaristia onde se partilha o Espírito de Cristo para uma vida cristã que seja imitação de Cristo, de modo que através dos "signos divinos" (theosemias) realiza a força (dinamei) e os efeitos (energeia) apropriados a cada signo, e assim "participa da vida divina" 162 ao receber o Espírito que purifica a vontade de suas ilusões e ilumina a consciência de suas contradições ${ }^{163}$. A theopoésis é a "comunicação e partilha da natureza divina" pelo Espírito "segundo as Escrituras"164.

Assim se a alexandria entende que a apatheia é a virtude por exce-

160. Ibidem, Contre les Païens, I, 10; 11,39; II, 21, 70.

161. Ibidem I, III, 9.

162. " $\Theta \epsilon o \hat{v} \mu \mu^{\prime} \theta \epsilon \xi \iota \nu$ ” cf. Cyrille d'Alexandrie. Sur la Trinité III - Col. Sources Chrétiennes, no 246 - Paris: Éditions du Cerf, 1978. Dialogue VI, 637,15.

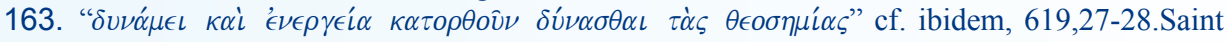
Cyril: Commentaire sur l'Evangile de S. Jean, livres I-VI (PG 73). Oxford: Pusey, 1872, II,5; Scholia de Incarnatione Unigeniti (PG 75, 1369-1420), 11.

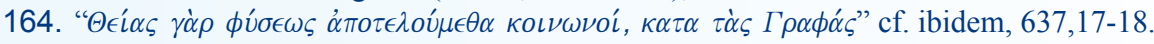


lência, a capadócia prefere a hesichia, a serenidade diante daquilo que a alma venha a sofrer, contando com um Deus que sofre junto pelas criaturas e se faz presente como convite a confiança em seu agir, resultado da iluminação e da purificação que constituem a catharsis gregoriana. A serenidade gregoriana é mediada pela poesia que permite alcançar a inexplicável beleza do amor de Deus, fonte de consolação, e alicerce para a liberdade de se desvencilhar das ilusões na medida em que descobre na gnose do batismo, caminho de verdadeira catharsis ${ }^{165}$ a fim de restaurar a verdadeira imagem de Deus, Alguém que sustenta e move a travessia da dor e do dever.

\section{Referência Bibliográfica}

ATHANASE D' ALEXANDRIE. Contre les Païens. Col. Sources Chrétiennes, № 18. Paris: Éditions du Cerf, 1946.

MOSSER, Carl. The earliest Patristic interpretations of Psalm 82, Journal of Theological Studies, NS, Vol. 56, Pt 1, April 2005.

CARVALHO, Margarida Maria de. Paideia e Retórica no séc. IV d.C - A construção da imagem do Imperador Juliano segundo Gregório Nazianzeno. São Paulo: Annablume Editora, 2010.

CATTANEO, Enrico; DE SIMONE, Giuseppe; DELL'OSSO, Carlos; LONGOBARDO, Luigi. Patres Ecclesiae - Uma Introduzione ala Teologia dei Padri dela Chiesa. Trapani: Il Pozzo di Giacobe, 2008.

GRÉGOIRE DE NAZIANZE. Discours 27-31 - Col. Sources Chrétiennes, no 250 Paris: Editions du Cerf, 1978, Or. 28,14-15

CLÈMENT D'ALEXANDRIE. Les Stromates I. Col. Sources Chretiennes, vol. 30.Paris: Editions du Cerf, 1931.

. Les Stromates II. Col. Sources Chretiennes, vol. 38.Paris: Editions du Cerf, 1954.

. Les Stromates V. Col. Sources Chretiennes, vol. 278. Paris: Editions du Cerf, 1981.

. Le Pédagogue I. Col. Sources Chretiennes, vol. 70.Paris: Editions du Cerf, 1960.

COSAERT, Carl. P. The Text of the Gospel in Clement of Alexandria - Col. The New Testament in the Greek Fathers. Atlanta: Society of Biblical Literature, 2008, p.2. 370 p

165. Ibidem, Discours 1-3, Or. 2,22 (118). 
GRÉGOIRE DE NAZIANZE. Discours 1-3 - Col. Sources Chrétiennes, no 247 Paris: Editions du Cerf, 1978, Or. 1, 4 (76).

. Discours 38-41-Col. Sources Chrétiennes, no 350 - Paris: Editions du Cerf, 1990, Or. 38,10 (122-124).

. La Passion du Christ. Col. Sources Chretiènne, no 149. Paris: Editions du Cerf, 1969.

GREGORII THEOLOGI. Patrologiae Cursus Completus, Series Graeca, PG 37-38.

GRENIER, A. La Vie et le Poésies de Saint Gregoire de Nazianze. Clemont-Ferrand: Typographie de Paul Huber: 1858, p. 130

Irineu de Lyon, Contre les héresies, livre IV. Col. Sources Chrétiennes, n. 100. Paris: Éditions du Cerf, 1965.

JAEGER, Werner. Cristianismo primitivo e Paidéia grega. Lisboa: Edições 70, 1991,

Justin. Apologie pour les Chrétiens. Sources Chrétienees, no 507. Paris: Éditions du Cerf, 2006.

KALLERES, Dayna. Demons and Divine Illumination: A Consideration of Eight Prayers by Gregory of Nazianzus In Vigiliae Christinae, 61, Literarure Department: University of Chicago, 2007, p. 174 (157-188)

KURIAN, George Thomas; SMITH, James D. The Enciclopedia of Christian Literature. Vol. 1: Genres and Types/Biographies A-G. Plymouth: Scarecrow Press, 2010.

LUBAC, Henri de. Exégèse Médiévale - Les quatre sens de l'Écriture.. Aubier: Editions Montaigne, 1959 (Première Partie I et Seconde Partie I).

MORESCHINI, Claudio; NORELLI, Enrico. História da Literatura Cristã Antiga Grega e Latina. Vol. I e II. São Paulo: Edições Loyola, 1996 e 2000.

NYSSENUS, Gregorius. Patrologiae Cursus Completus, Series Graeca, PG 44.

PERINE, Marcelo (org.) Estudos Platônicos - Sobre o ser e o aparecer, o belo e o bem. São Paulo: Edições Loyola, 2009, pp. 91-112.

PHILON D’ALEXANDRIE. La Migration d'Abraham. Col. Sources Chrétiennes, n. 47. Paris: Les Édition du Cerf, 1957.

SPINELLI, Miguel. Helenização e Recriação de Sentidos - A Filosofia na Época de Expansão do Cristianismo - Séculos II, III e IV. - Col. Filosofia, № 145. Porto Alegre: EDIPUCRS, 2002.

STORIN, Bradley. In a Silent Way: Ascetism and Literature in the Rehabilitation of Gregory of Nazianzus In Journal of Early Christian Studies, vol. 19, num.

2. The John Hopkins Universtity Press, 2011, pp. 225-257. 